ASBURY THEOLOGICAL SEMINARY OCT ONIVERSARY SPECIAL EDITION

\title{
The Person and
} Work of Jesus

20x

5

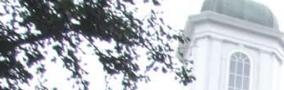

Bit A $^{3}$.

\&

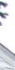

Christ

Robert W. Lyon

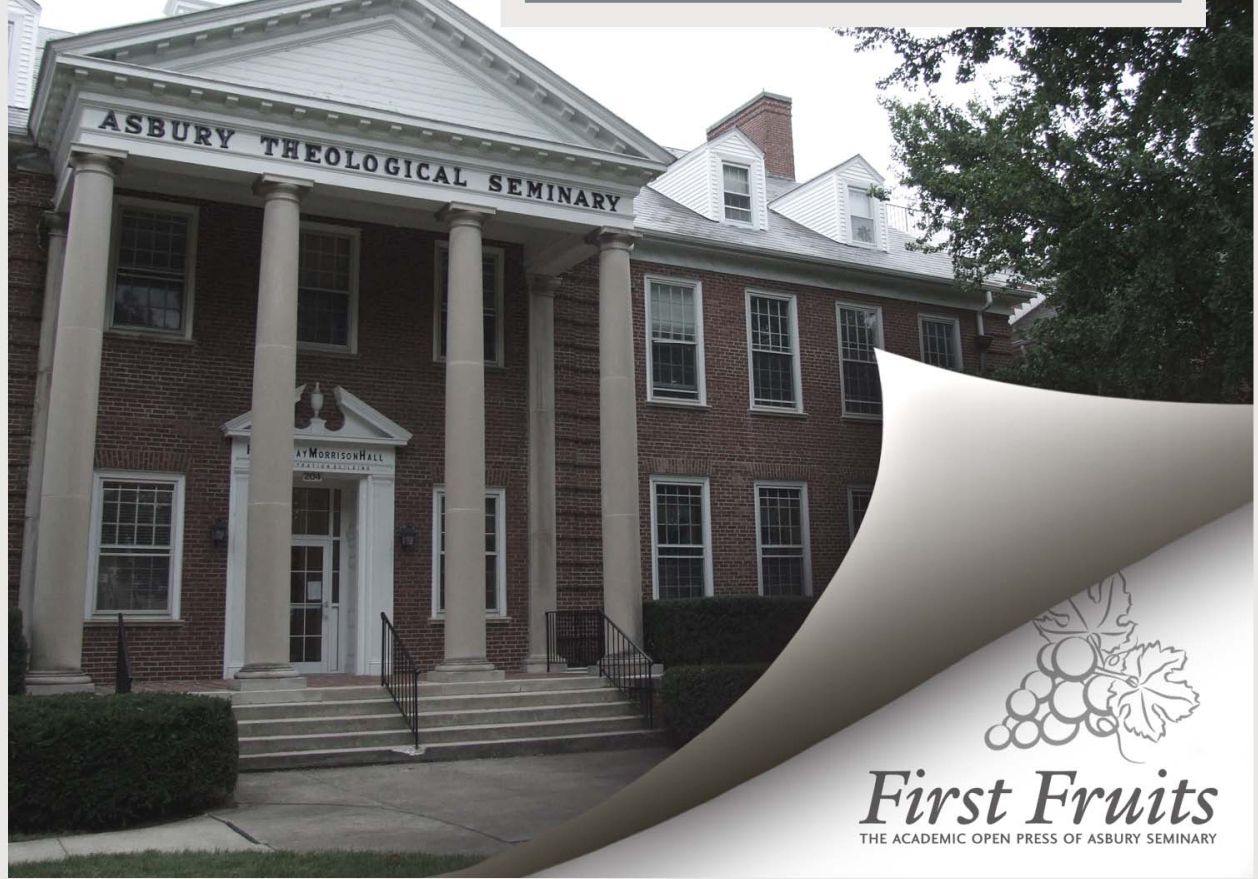


DOI: 10.7252/Paper.00006

The Person and Work of Jesus Christ

By Robert W. Lyon

Digital version at

http://place.asburyseminary.edu/firstfruitspapers/9/

First Fruits Press is a digital imprint of the Asbury Theological Seminary, B.L. Fisher Library. Asbury Theological Seminary reserves the right to release new editions of this material as well as new material produced by Asbury Theological Seminary. Its publications are available for noncommercial and educational uses, such as research, teaching and private study. First Fruits Press has licensed the digital version of this work under the Creative Commons Attribution Noncommercial 3.0 United States License. To view a copy of this http://creativecommons.org/licenses/by-nc/3.0/us/.

Questions, contact:

First Fruits Press

B.L. Fisher Library

Asbury Theological Seminary

204 N. Lexington Ave.

Wilmore, KY 40390

http://place.asburyseminary.edu/firstfruits

Cover Design by Kelli Dierdorf

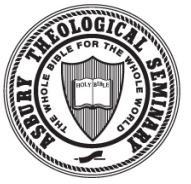

asburyseminary.edu 800.2ASBURY 
DOI: 10.7252/Paper.000006

\section{The Person and Work of Jesus Christ}

Robert W. Lyon

October 24, 1973

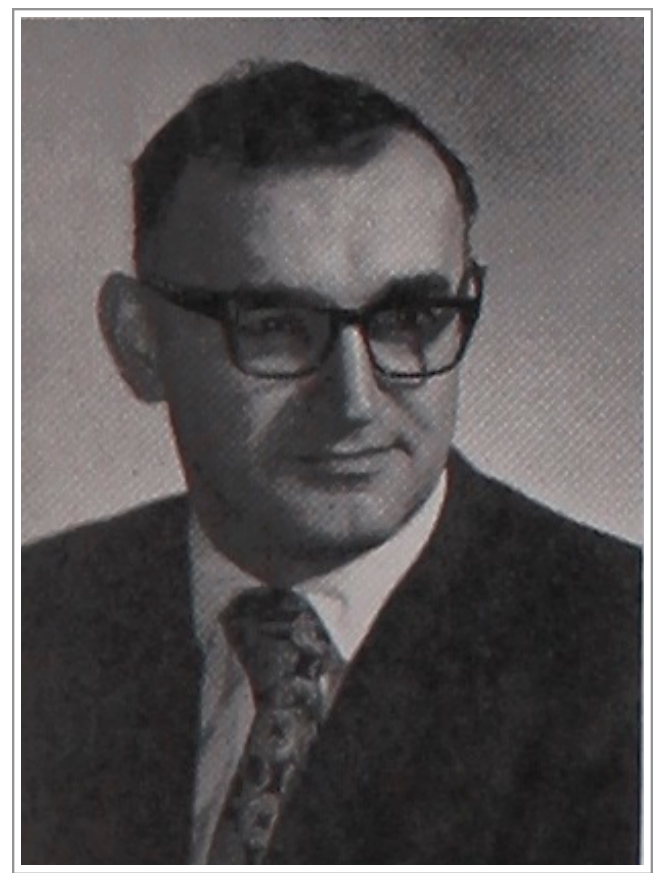




\section{Introduction}

An essay about Jesus Christ is an essay on Christology and so must begin with a definition: does Christology consider only the person of Christ and leave the work of Christ to be treated under Soteriology, as R. H. Fuller suggests? ${ }^{1}$ Or does Christology involve both the person and work of Christ, as Cullmann assumes? ${ }^{2}$ Because it is virtually impossible to discuss the person of Christ without discussing his work, and because the early Church for the most part approaches the person of Christ through and in terms of his work, we find the approach of Cullmann much to be preferred-indeed inescapable. But the definition of Christology is not so easily solved, for in a theologically significant sense Christology should include not only what he has done, but what he is doing now in the Church through the Spirit and what he will do when he comes again. Any full statement of the "work of Christ" ought, therefore, to include the past (i.e., the "historical" Jesus), the present, and the future.

As to sources we may confine ourselves to the New Testament canon since extra-biblical sources add almost nothing to our knowledge, are almost all later than the New Testament documents, and, whether orthodox or otherwise, theologically tendentious. ${ }^{3}$

As sources the New Testament documents give us the primitive account of the ministry of Jesus and the apostolic response. They contain both description of the Word become flesh and interpretation of the meaning and significance of the event. This twofold reference to the New Testament documents as description and interpretation brings us to the heart of our understanding of the New Testament as an inter weaving of event and response. It is the New Testament of Jesus Christ in that from beginning to end it is the result of his ministry and word. We find not only the story of Jesus but also how the significance of that story was shared with varied audiences and how it addressed various issues. Any essay must 
preserve and relate this richness and diversity of the biblical witness.

At this point it is necessary to set forth very briefly some concerns and convictions, which determine the character of the rest of this essay. We need to assert at once the primacy of the ministry and message of Jesus in all theological reflection. Apostolic doctrine is not only subsequent to, but also subservient to, derived from, and dependent upon that ministry and message. Jesus as the Son and the Word of God (Hebrews $1: 1 \mathrm{ff}$; John $1: 1$ ) is he by whom all former Scripture and all subsequent apostolic doctrine are measured. His word and being determine how we shall approach all the biblical tradition. What we have in the New Testament are two events - the ministry of Jesus and the ministry of the primitive Church. The former is immediate, the latter mediate: that is, the latter grows out of the former and obtains its significance through the former. A survey of New Testament Christology must necessarily, therefore, give major emphasis to that first event. Otherwise we face the danger that the ministry of Jesus is viewed as only the originating impulse and so give the impression that the nature of Christianity was determined by the early theologians such as Paul, John, or Luke. Major epochs of church history have not avoided this pitfall.

We need to recognize at the same time that all the New Testament documents are post-Easter literature and grew out of the life and work of the Church. The gospels are not objective history, that is, written without bias. On the contrary they are evangelistic-apologetic-didactic. They give the story of an event told by those committed to it, who believe their own lives have been transformed by it, and told for the purpose of drawing others to faith in Christ. The gospels were written out of a passionate desire to make Jesus Christ known and to create a community, which fulfills his commission to it. In all four gospels the story is set forth not only to show how eyewitnesses recalled the events, but also in such a way and in such terms as to portray their own faith. They contain the faith of 
the community as well as the story of Jesus, a fact that needs to be kept in mind if the gospels are to be understood rightly and if we are to avoid falling for some modern false alternatives. The selection of material, its arrangement and, in part, its vocabulary belongs to the evangelists and to the early Church to meet its needs and serve its purpose.

At the same time the material is historical and, within limits, biographical in that it records what was said and what happened. The basic reliability of the material, the variations within it notwithstanding, is established by the fact that the early Church defined the nature of its faith on the basis of what happened. The historical basis of its message was Jesus and his word. The early Church knew that the historical roots of its kerygma were a basic asset in comparison with all contemporary religious propaganda. Even Judaism had become largely a-historical in its treatment of its traditions. But Christian faith was faith in Jesus Christ about whom they had reliable traditions. New congregations were formed and rooted in those traditions.

\section{The Word Become Flesh}

It is necessary at the outset to point out that a summary of the ministry and word of Jesus is not due to biographical interests, but is rooted in the fact that the story of Jesus is the proclamation of the early Church, that it informs us of the nature of biblical faith and thereby becomes the precipitant of faith. The story begets faith and for this reason it is set out again. We have little interest in a life of Jesus as such, but in what the early Church proclaimed, that is, the story of Jesus.

A capsule presentation of the ministry and word of Jesus is required also by the fact that Jesus is seen in Scripture as the subject of all Christian experience. He is Actor. He is not only the object of faith but also its subject. The Spirit is the Spirit of Jesus Christ whom Jesus sends and who mediates the work of Christ. Jesus is Lord, sovereign subject, and by virtue of his atonement all men stand before him. For this reason we are 
able to speak of "normative" Christian experience and question those so-called "movements of the Spirit" which appear to move independently of the Jesus tradition. This tradition is the primary means of telling us what faith and obedience involve. This tradition gives substance to Christian freedom. ${ }^{4}$

The Proclaimer. Two of the four evangelists begin their story with the birth of Jesus. Although the accounts differ considerably, both include features, which underscore their primitive and Semitic character. Both tell, for example, of the birth largely in terms of Jewish thought and forms. The narratives are unadorned, straightforward and restrained-with due allowance for the Lucan hymns. In neither account do we find any exaggeration or elaboration of the miraculous birth: in due course Mary, the virgin, gave birth to a child to whom the name Jesus was given. Both accounts relate the virgin birth to the work of Christ (Matthew 1:21; Luke 1:32) in redemption and it is this, which gives the virgin birth its significance. The circumstances of his birth point to his unique ministry as Messiah and Savior of the world. This is the consummate act of God (Hebrews 1:1ff). In that the transcendent God enters into human history to initiate that final work which will eventually bring about the redemption of all things. The virgin birth serves to underscore the decisive character of the work of Christ; that Is, it is a sign in that it directs proper attention to the One coming into the world. Though in the primitive Church the virgin birth did not bear the same importance as the resurrection, the evidence suggests that it was told as serious history, that it was known and received in Semitic and Hellenistic communities as the opening into the Christian Gospel. The church that ignores the virgin birth will sooner or later fail to recognize the ultimately decisive ministry of Jesus and find itself struggling to comprehend what is the substance of Christian proclamation and faith. ${ }^{5}$

The Beginning of Ministry. Little is said about the life of Jesus prior to his baptism by John when he was about thirty years old. And it is not for the Church to speculate (or preach) 
on these "hidden years." The goal of gospel research is not primarily biography, but a recalling and hearing again of that ministry and word to the end that men may believe. This is

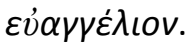

All four gospels agree that his ministry began at his baptism, which served as a sign of his solidarity with humanity and his commitment to the human predicament. We find no evidence to believe that Jesus came like others seeking repentance and forgiveness and that in the baptism "sensed" his call. His baptism at the hand of John creates a correspondence with the message and eschatological focus of John. At his baptism the Spirit comes "upon" or "into" him (cf. Mark 1:10, parr.); this too signifies what is taking place. The pouring out of the Spirit was to indicate the inauguration of the new age, which was to be the age of the Spirit. The reading of Isaiah 61 in the synagogue in Nazareth is seen by Jesus as an opportunity to define the character of his ministry. He is the eschatological messenger who is to fulfill the promise to the fathers (Luke 4:16ff). He casts out demons by the Spirit of God (Luke: finger of God) and this is ground for recognizing that the Kingdom has in fact come (Matthew 12:28). Thus equipped Jesus becomes the proclaimer of the new age for the people of God.

The ministry of Jesus is a combination of success and apparent failure, gladness and hostility. It takes place within the religious community, but also outside it. His disciples are never far away. In order to gain an adequate perspective we shall attempt to describe the word and ministry of Jesus as it related to the religious establishment, to the masses and finally to the disciples.

Ministry to the Devout. Our sources agree that Jesus taught in the synagogues, ${ }^{6}$ that he raised questions of the Law and that people were often taken back by his authority and wisdom. In contrast to the Baptist, Jesus attempted to work within the establishment. Yet his ministry has a special thrust. Our gospels portray the leadership of synagogue and temple as 
moribund, bound by its own traditions, in bondage to a repressive view of Scripture and lacking in any type of spontaneity by which care and love might be expressed. The harsh words of Jesus are always directed toward the religious leadership, not because they were a threat to him, but because they were leading the people into, rather than out of, bondage. By their traditions they had cancelled out the commandments of God (Mark 7:11), which even when held were given a rigid and narrow, rather than expansive, reference (Matthew 5:2148). They were preoccupied with minutiae and neglected the weighty matters (Matthew 23.23). The reductio ad absurdum is to be found in the debates over the Sabbath, especially those involving healing miracles. The debates that followed these events reveal a distorted sense of values, which gave preference to the cult over against the Word of God and human compassion.

But we must note another issue raised by Jesus vis $a$ vis the establishment. Not only was it largely oppressive and without compassion: it was also guilty of violation of the Old Testament revelation in terms of their view of God, the covenant and righteousness. The moments of pathos in his ministry are when he sees their resistance hardening. It is tragic when, as with the prophets, the Word of God is not heeded, but it is infinitely more painful when the elect miss the moment of fulfillment, because afterward all is darkness (Matthew 23:37ff; Luke 13:34ff; 19:41ff). In the end it is Jesus' independence of human tradition and his binding himself to the Father's will that brings about the concluding events. A caveat may not be out of order. When Jesus set himself against authorities, it was because they had set themselves against the purpose of God. His was no arbitrary independence. He stood by the common expressions of faith in his regular habits of prayer and attendance at the synagogue. He bore the burden of his people's sins from within the community. His was an identification with the nation, including its leaders. He did not 
think in terms of classes of men, but in terms of men before God.

Ministry to the Masses. The hostility toward Jesus on the part of the religious leadership was due in no small part to his willingness to relate to the outcasts of society. Perhaps the most distinctive feature of his ministry was his contact with the masses both outside and inside the religious institutions. His beatitudes are directed to the dispossessed. He gives time and support to the friendless. He refuses to discriminate when it comes to dispensing the Word of God and the offer of forgiveness. He is found in the home of tax collectors and sinners. He allows a prostitute to wash his feet. He alone hears the cries of the people and offers a blanket invitation. ${ }^{7}$ His ministry is one of "release to captives" in the broadest sense.

Numerous parables reflect this aspect of his ministryas e.g., the parable of the Pharisee and the Tax Collector, the rich man and Lazarus, the sheep and the goats, the prodigal son and the great banquet. Here we see his positive message: in the climactic Day of the Lord all men are encouraged to come and taste of the water of life freely. The great central fact is the free grace of God to all men. The banquet is ready and the call has gone out. The pious are not allowed to stand in the way or to preempt the best seats. The last are first; Lazarus has his place; the prostitute is set free. Zacchaeus is allowed to host the Son of Man. All traditional patterns of a stratified society are shattered in the presence of the Word. All prerogatives are overturned. The Word of God is a Word for all men, and no man regardless of office may impede its outward flow. Jesus marches on- creating hope, offering liberty, restoring sight, and preparing a people for the Father.

Ministry to the Disciples. There can be no doubt that a core of followers participated in Jesus' ministry. Luke refers to the sending out of seventy-two to proclaim the same message and to take part in the same healing ministry (10:1ff). But for the most part the traditions have in mind a group of twelve, who clearly play a special role. The synoptic tradition is not 
always clear in defining their relationship to Jesus - and even gives different names when listing them. Yet at the same time it is quite clear that Jesus gave himself to them in a special way. They accompanied him by special invitation; they "imitated" his ministry when they were sent out (Mark 6:7; Luke 9:1). They were given special instruction, undoubtedly for the time when he would not be with them. Some of the parables are interpreted privately to them - in spite of much recent criticism that regards this material as later and redactional.

They are disciples because he has called them, a clear distinction from the disciples of contemporary rabbis who attached themselves at their own initiative to the rabbi of their choice. Furthermore, the twelve were disciples by virtue of their participation with him in his ministry. They were an extension of his ministry at the same time they were learning from him.

In these three aspects of his ministry to the established religious community, to the masses and dispossessed and to the disciples we see the unfolding of the nature of the three traditional "offices" of prophet, priest and king.

The Consummation of Ministry. Though Jesus knows the nature of the consummation of his ministry, events begin to rush on with ever increasing speed. He is conscious that he must end his ministry in Jerusalem, and it is his decision to go to the sacred city that is the real beginning of his passion. There can be little doubt that the event, which precipitated his death, was the cleansing of the temple, an act that must have been especially appalling in view of the festive atmosphere. The die is now cast.

In recent times scholars have debated the nature of the final accusations against Jesus as well as the question of who was finally responsible for the execution. The variations in the narratives do not help. Some have argued that the charges against Jesus were political in view of his claims of kingship and authority; therefore he was removed by Roman authorities, though not without support from Jewish leaders. The argument 
from this view is that only Roman officials could carry out the death penalty. Some, on the other hand, have argued that Jesus was only a threat to the religious establishment and that the events leading to his death were staged by the Jewish hierarchy. ${ }^{8}$ This latter view seems much to be preferred. His ministry was to the lost sheep of the house of Israel and it was this house that did him in. "He came to his own and his own people did not receive him." We have no clear evidence that Jesus was regarded as a menace to Roman authorities. Recent attempts to link him with zealot-type movements have failed to demonstrate their thesis. ${ }^{9}$ Every stratum of the early tradition (Mark, M, Q, L, John, Paul, the early sources in Acts) associate the crucifixion with the conniving of Jewish, not Roman, officials. The supposed desire of the early Church to minimize the role of Roman authorities cannot account for the widespread tradition that Jewish leadership, with a legal assist from Rome, put him to death.

But he was raised from the grave and his work entered a new phase. The resurrection narratives are extremely difficult and probably impossible to harmonize. All are extremely selective and their authors have telescoped the accounts so that we simply have no way of piecing together all the separate items. In addition the unique character of the resurrection leaves us without criteria for a thoroughgoing historical study. One thing, however, can be said for certain: attempts by scholars such as Bultmann, John Knox and Don Cupitt ${ }^{10}$ to define the resurrection in terms of the faith or memory of the primitive Christian community have not stood the test of scholarly scrutiny. They are derived not from the available texts but from a philosophical base. While these men manifest a deep concern to understand the resurrection, at the same time they fail to show evidence of a subordination either to the New Testament itself or to historical method. The resurrection is the resurrection of Jesus whom God raised to his own right hand (Acts 2:33); so then the risen Jesus is now Lord of the Church and the bestower of the Spirit. 
During the period of the appearances Scripture informs us that Jesus sought to show the disciples why all has taken

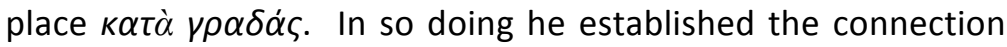
between his ministry, death and resurrection and their faith; this was a resurrection faith given substance and direction through their reflection on his prior ministry. Their faith was not in the risen Jesus but in Jesus who had been raised. Thus everything they knew about him was constitutive for their faith and part of the proclamation, which sought to bring about faith.

The Proclamation. Having taken a brief overview of his ministry we must now consider his Word. The most common term by which he is addressed is "teacher." We read repeatedly that he was found in the synagogues teaching. Scholars remind us that Matthew and Luke differ from Mark in that they record more of the teaching material, yet at the same time it should be noted that Mark makes more references to the fact that Jesus taught than either Matthew or Luke. That the Old Testament played a large part in his teaching is to be seen in the fact that much of his teaching took place within the synagogues of the villages and cities. Yet his teaching was much more than a rabbinic-type discussion of fine points of the Law.

The best-known feature of his teaching ministry was the use of the parable, whose function is more closely related to the Old Testament mashal than to the rabbinic. Its basic purpose is not so much to inform or instruct in a formal way, as it is to challenge to decision and action. ${ }^{11}$ They are essentially kerygmatic in that they relate to the good news of judgment and grace. They call attention to what Jesus is doing and the crucial significance of his being with them. The parables underscore the nature of the moment and the opportunity opened up by his presence. They are both frightening in terms of impending disaster (The Ten Maidens, Matthew 25:1ff) and enthralling in the character of grace that is portrayed (The Lost Son, Luke 15:11ff). The important point is that they relate to the ministry of Jesus - that is, they represent what may be called a "homiletical commentary" on Jesus' ministry. 
As a part of his preaching and teaching ministry the gospels give great prominence to his healing ministry, which is regarded by Jesus as a ministry of compassion. But we associate it with his teaching ministry because we have clear evidence that he also intended it to be indicative of the new situation created by his coming. We note how frequently preaching and healing are associated together (Matthew 4:23; 9:35; 10:7f; 11:2ff; Mark 1:38f; 3:14f; 6:12f; Luke 7:18ff; 8:1f; 9:1f). When challenged by certain Pharisees about a miracle, Jesus declared that it was a substantiation of his message of the arrival of the Kingdom (Matthew 12:22-28; Luke 11:14-20). These miracles of Jesus represent the power of the new age, which has power over Satan, and so signal the imminent end of Satan's dominion. The fourth gospel by referring to the miracles as signs (e.g., 2:11) underscores this aspect. Though Jesus is portrayed as refusing to give a sign "on demand" (Mark $8: 11 \mathrm{f})$, at the same time he does indicate that these mighty deeds are a pointer toward an adequate assessment and response to his Word.

The Kingdom of God. "After the arrest of John, Jesus came into Galilee preaching the Good News from God, saying, 'Time is fulfilled and the Kingdom of God has come; repent and believe in his Good News," (Mark 1:14f). Anyone who is familiar with the synoptic tradition cannot doubt that at the heart of his ministry was this proclamation of the Kingdom of God. (Matthew's "Kingdom of Heaven" is merely a Jewish circumlocution and has no separate or special meaning.) But the question is: what did Jesus proclaim when he proclaimed the Kingdom? The answer is to be found by reference to the Old Testament and the intertestamental literature. In the prophetic literature God rules alone over all the world. $\mathrm{He}$ is King. But it is also painfully obvious that in some very real sense He does not yet rule, as He will some day. So there is frequent reference to a future day of the Lord when He shall truly rule. The hope of the people of God is focused on a day when he will act to fulfill all the promises to His people. This comes to 
apocalyptic expression in Daniel 7. Thus, when Jesus came proclaiming the Kingdom; he aroused the eschatological aspirations of the people and created a climate of fulfillment. His language is "fulfillment language." In Nazareth he reads from Isaiah of the acceptable year of the Lord and speaks of its present fulfillment (Luke 4:18). His casting out of demons is a similar pointer. The first point, then, to note about the proclamation of Jesus is its eschatological character - a point caught in the Nunc Dimittis of Simeon: "Now, Lord, let your servant depart in peace according to your word; for my eyes have seen your salvation...," (Luke 2:29f). With the ministry of Jesus a sense of finality enters history and a new stage is set.

A second major point focuses on the tension between the present and future, between fulfillment and "not yet." On the one hand a number of texts seem to speak unmistakably of the arrival of the eschatological moment. But just as clearly there is a "not yet" aspect which cannot be denied. We err when we attempt to explain one aspect in terms of the other, or to choose one at the expense of the other. The whole tenor of the ministry and message of Jesus is that now men may participate in and enjoy what generations have longed to see. Yet it is equally true that the Kingdom is still future in an ultimate sense. Men may now enter the Kingdom and experience God's saving work, but it is a work still to be consummated. Paul expressed the same tension by speaking of the $\alpha \rho \rho \alpha \beta \omega \dot{v}$ (Ephesians 1:14), the "down payment" until such time as the whole is possessed. The present aspect of the Kingdom does, however, underscore the definitive character of Christ's offer of forgiveness, freedom, and joy, while the future aspect makes all labor in the Kingdom anticipatory. "He who loses for my sake shall receive a hundredfold."

A third point that is to be stressed relative to the Kingdom is its close relationship to the person of Jesus himself. In Luke 18:29 we read of those who leave their homes and families "for the sake of the Kingdom of God," while the parallel passages in Matthew and Mark read respectively, "for the sake 
of my name" and "for my sake and for the sake of the Gospel." In Mark 9:1 Jesus speaks of those who will not taste death before they see the Kingdom having come in power, while the Matthaean parallel refers to seeing the Son of Man coming in his Kingdom. When we move outside the synoptic tradition the language and references of identification are more varied. Both Jesus and the Kingdom are proclaimed as the Gospel. ${ }^{12}$ Christians pray both for the coming of the Kingdom and for the coming of the Lord. ${ }^{13}$ Men are said to receive the Kingdom and Christ. $^{14}$ Both the Kingdom and Christ are at the same time present and yet future. ${ }^{15}$ Both are spoken of in terms of absolute commitment and sacrifice. ${ }^{16}$

What does all this mean? Can we summarize what the Kingdom of God is? It is the announcement by Jesus that in his own coming, his ministry and Word, the final Word of God is being spoken in incipient form. This word is so identified with himself that he draws men to himself and becomes both the precipitant and the object of their faith. The proclaimer becomes the proclaimed in a natural and necessary way in that the event that inaugurates the Kingdom (viz., the work of Christ) is spoken of in the same way as the Kingdom. Thus some of the parables of the Kingdom, such as the parables of growth, the fish net, the sower and the wheat and the weeds, are really attempts to explain the ministry of Jesus. All these relate to the power of the Word and to ultimate success, though in the present ministry of Jesus one sees very little of what is supposedly to characterize the eschatological Kingdom. But to receive his word is to be transferred into a new age, to enter into life, to enjoy the freedom of true deliverance, and to anticipate ultimate fulfillment of the whole purpose of God.

The Son of Man. Much scholarly effort has been directed toward an understanding of titles, especially titles Jesus may have used or accepted. By what titles did he refer to himself? And what was his attitude toward other titles? Negatively, it seems quite clear that he avoided the title "Christ" or "Messiah," though that is not to say it was an inappropriate 
title. After Peter's confession at Caesarea Philippi the disciples are directed not to use the term. At the trial the High Priest asks if he is the Christ. The answer of Jesus differs in the three accounts. What we appear to have is a refusal to deny the title and at the same time an unwillingness to use it. Richard Longenecker, following a suggestion by David Flusser, has suggested that the reason for Jesus' reticence to use the title is due to the contemporary concept that the Messiah is not to claim the title until after his work is accomplished. ${ }^{17}$ On this question, however, we have no certain answer.

But perhaps the best way to consider the messiahship of Jesus is by way of the one title, which the tradition indicates was his chosen self-designation, and that is the Son of Man. An enormous amount of literature has sought to identify the origin and significance of the term. ${ }^{18}$ Clearly the problems are not simple. Outside the gospels the title appears only twice in Revelation and once in Hebrews (all quoting the LXX) as well as on the lips of Stephen at his stoning (Acts 7:56) Within the gospels it is always used by Jesus. At times he appears to be referring to someone other than himself, as in Mark 8:38, and this has lead some, e.g., Bultmann ${ }^{19}$ to conclude that Jesus did not regard himself as the Son of Man, but as the one who was to precede the arrival of that Son of Man. But this position creates more- and more difficult- problems than it solves. Without attempting to pass over very difficult problems it seems that in the synoptic tradition and in the fourth gospel the use of the Son of Man as a self designation correlates well with the other data to portray the obliqueness or hiddenness of Jesus' earthly ministry, while at the same time indicating the basis for his personal authority and power. As the Son of Man he is Head of the new man, yet he comes as one who serves. It is an excellent example of the ability of Jesus to draw into his own ministry various and divergent themes to portray the character of his work. As Eduard Schweizer has said, he fits no formula. ${ }^{20}$ His ministry is not determined by set formulas, 
traditions, texts, or popular expectations. Rather formulas and traditions develop on the basis of that ministry.

With this in mind it seems impossible to believe he regarded his ministry as anything other than messianic. It is eschatological in substance; it is a ministry of direct and immediate authority and power. It is an inclusive ministry, which sets history on the threshold of a new age. By every measure he himself was messianic in perspective, scope, and purpose. Nothing was left for another to do after him. ${ }^{21}$

\section{The Word in the World}

The New Testament defines and describes the work of Christ through various themes and motifs, and it is important for the Church not to reduce this variety for the sake of uniformity. No doubt the origin of much of this diversity lies with Jesus himself, but in part it arose due to the issues, which confronted the early Church. It is impossible in the brief compass of this essay to set forth fully all that the New Testament says about the work of Christ; therefore only basic themes will be treated.

The Death of Christ. The crucifixion represented for early Christianity both a stumbling block and its crowning glory. Its centrality for the primitive kerygma is seen not only in the explicit statements in the epistles but also in the fact that the passion narrative takes up a large part of all the gospels and in the fact that a significant part of the New Testament vocabulary (e.g., blood, cross, baptism, Eucharist) derives from the death of Jesus. We have every reason to believe that meaning and significance began with Jesus himself. Despite attempts to regard the passion predictions of Jesus (Mark 8:33; 9:33; 10:31 and parr.) as vaticinia ex eventu of the early Church, ${ }^{22}$ there is good reason for Jesus, if he attached any meaning to his impending death, to have spoken about it beforehand. J. Jeremias, for example, has pointed out that in the contemporary Jewish tradition a martyr's death may have atoning significance attached to it, but only if that atoning 
significance is stated beforehand. ${ }^{23}$ It may be noted, further, that reference to the death of Jesus is found throughout the tradition, and not least in the parables. How does it come through?

N. Snaith has suggested that Jesus deliberately modeled his whole ministry on the concept of the suffering-triumphant Servant of Isaiah. ${ }^{24}$ It would probably be better to say that it was one of the models, since his ministry really fits no single model. The servant consciousness of the early Church is derived from its Lord whose purpose was to do the Father's will. The idea is expressed in Jesus' comments on greatness (Mark 10:43ff), in the Johannine account of the foot washing (13:1ff, especially verse 14) and more generally in what is often called the "hidden" character of his ministry. The cross is seen as the culmination of that servant posture and as embracing all that the ministry itself meant. For him to be servant ( $\delta$ oṽ $\lambda \circ \varsigma$ ) means even to give his life as a means of redemption for many (Mark $10: 45) \mathrm{He}$ is the one who by ministry and death has set men free (John 8:36; chapter 17). The life and death of Jesus are seen together and cannot be separated. Thus Paul, when he proclaims Jesus Christ and him crucified, is not expressing indifference to the material of the synoptic tradition as though he had no interest in or knowledge of the earthly Jesus. For the early Church the "cross" meant the whole ministry culminating in crucifixion. In this sense, the gospels are as a whole to be seen as passion narratives. This may be seen in the Acts, which recognizes the gospel as beginning with the baptism of John $(1: 21 f, 10: 37)$ and yet still embodies a theologia crucis. By his total obedience (John 17:4) Jesus gives access to the Father.

But the Church also recognized the priestly character of the work of Jesus by drawing upon the sacrificial motifs. He is seen as the one whom God set forth to be the means of atonement for the sins of the world (Romans 3:25). It is by his blood that we have redemption (1 Peter $1: 19$ ). He is seen as the sacrificial lamb (Revelation 7:14; 1 Peter 1:19; John 7:29, 36). ${ }^{25}$ Such references are to be taken seriously when working 


\section{2 | The Person and Work of Jesus Christ}

through the meaning of the death of Christ, and at the same time related to other categories with which they are often bound. Thus the sacrificial focus stands with the idea of deliverance because sin is personified as a power by which man is enslaved and from which he must be freed. Romans $3: 24 \mathrm{f}$ is a good example of this comingling of categories as Paul attempts to portray the all-encompassing achievement of Christ.

Closely related to these themes is the idea of substitution, the removal of which from the New Testament cannot honestly be achieved. Though $\alpha \dot{v} t i$ is found only infrequently in the New Testament, $v \pi \varepsilon \rho$ is clearly to be seen as its equivalent in a number of passages. F. C. Baur himself recognized the clearly substitutionary character of 2 Corinthians $5: 14 .^{26}$ And more recently $G$. Delling has made the same point for Romans 5:6-8. ${ }^{27}$ We can see also the same perspective in the Eucharistic words of Jesus as well as in the ransom saying. At the same time it must be said that not all attempts to develop a substitutionary theory have been successful; indeed some have been little more than a new legalism.

The general term by which the meaning of the death of Christ is defined is "atonement," a word found in the New Testament only in Romans 5:11 in the AV and not at all in the RSV. But it seems to express what takes place by virtue of the work of Christ in that man by faith comes to a knowledge of God. Various theories of atonement only approximate biblical realism; all have their limitations and problems. It is not possible for a single "theory of atonement" to encompass all that Scripture expresses, since Scripture is so fully orbed and multi-faceted. The term redemption relates to the idea of slavery and deliverance from it; reconciliation speaks of the removal of barriers and the establishment of fellowship; propitiation relates to wrath; expiation to sin; forgiveness to guilt; justification to judgment. At the center is the conviction that Christ by his obedience (Romans 5:15ff) and death has made available to mankind the new and living way and has become the pioneer and perfector of our faith. 
The Resurrection. That Jesus had been raised from the dead and was alive was the basic conviction of the early Church, the character of whose worship, ministry, and message was shaped by it. Two additional points were equally clear: (1) that he was raised by God; and (2) that his resurrection was at the same time a transformation unbound by that which characterized his incarnate ministry. That is, it was an "eschatological" resurrection (Paul's "spiritual body" 1 Corinthians 15:35ff) of the type all believers shall have at a future time.

Knowing, then, that the resurrection was not after the manner of other restorations of life (such as Lazarus), the Church had to understand and interpret its meaning which needed to be as all-encompassing as the event was unique. In the first place the resurrection was seen as the vindication of Jesus, his whole ministry and his word. The Church repeated the story because it had been confirmed by the resurrection. The preaching of the early chapters of Acts expresses this point clearly: you crucified him, but God raised him from the dead! Though the precise meaning of passages like Romans 1:4 and Acts 2:36 are difficult to determine, it is at least clear that by the resurrection Jesus is established as effective Son of God and takes his place at the Father's right hand (cf. Acts 2:33; Colossians 3:1; Romans 8:34).

Secondly, the resurrection is viewed not only as a vindication of Jesus but as a triumph over sin, death, and the forces of evil. He was raised with a view to our justification (Romans 4:25). ${ }^{28}$ If it is not true that Christ has been raised, then we are foolish to believe; and moreover we are still sinners (1 Corinthians 15:17). The latter part of this chapter rings of the triumph over the grave: death has lost its sting. He is the firstborn from the dead (Colossians 1:18) and so the first among many (Romans 8:29). He is the first fruit of those who sleep (1 Corinthians 15:20). His resurrection is the antecedent to Christian life, the character of which is defined by the resurrection of Jesus. As Christ was raised from the dead 
74 | The Person and Work of Jesus Christ

through the glory of the Father, thus we walk in new life (Romans 6:4). Our hope is grounded in the resurrection of Jesus (1 Peter 1:3).

It is no exaggeration to say that all the theology - and of course all Christology - has the resurrection as its focal point. It opens up the full meaning of the Old Testament (Luke 24:45). The narrative of our Lord's ministry is stamped by it. The gospels are indeed post-Easter narratives; one cannot conceive of any early Christian writing or liturgy that did not reflect the Easter-faith of the Church, for there can be no other starting point. From the resurrection on, God is not the "God of Abraham, Isaac and Jacob" but the God who raised Jesus from the dead (Acts 2:32; 3:15; 5:30; Romans 4:24; 8:11; Galatians $1: 1)$. God is spoken of in terms of His primal act and all else that God has said and done is to be fitted into a structure built on that act of power. All ethics are rooted in the resurrection, since New Testament ethics are predicated on the fact of new life. Christians are described as having passed through a death and having been made alive (Romans 6:1ff; Galatians 2:20; Colossians $3: 1$ ). The Christian life is characterized by power, but it is the power of his resurrection, which is presupposed, e.g., in Paul's pressing toward maturity in Christ (Philippians 3:9-16).

The Lordship of Christ. Jesus as Lord is the basic confession of the early Church and the most common ascription to him in the New Testament. The Lordship of Jesus is tied to the resurrection in Ephesians 1:20-23: by His own might God raised Jesus and seated him at His right hand in heaven; God has put all things under his feet and made him Head of the Church. Christ as Head of the Church is the risen Lord. Something of this is expressed in the Pauline expression $\dot{\varepsilon} v$ $\chi \rho \iota \sigma \tau \tilde{\omega}$ in that Christ now holds the dominion over the Church that Adam has held since the fall (cf. Romans 5:12ff; 1 Corinthians 15:20). He exercises this Lordship over the Church through his Spirit, his gift to the Church. The Spirit is not Lord but makes the Lordship of Christ present. It is to the Church's advantage that Jesus departs, for then the Spirit may come and 
continue his (Jesus') ministry in an ever-expansive way. The Spirit is the Spirit of Power, but it is the power of God and of the risen Lord. Being led by the Spirit (Romans 8:14) means to be subservient to the Lordship of Christ. That is the reason why the early Christians did not rely solely on private or personal inspiration in daily life but made themselves dependent on the Jesus-tradition and the Old Testament. The gift of the Spirit was no invitation to individualism, but a means by which all former words of God (Hebrews 1:1) were interpreted and related to the one Word given in the last days.

Another point to be noted is that the early Church looked upon itself as the continuation of the ministry of the incarnate Jesus. Note, for example, the correlative expressions in the latter chapters of the fourth gospel: as I have washed your feet...(13:15); as I have loved you...(13:34); as I have kept my Father's commandments and abide in His love...(15:10); as You have sent me into the world...(17:18); just as we are one...(17:22); as the Father has sent me (20:21). Theologically, the description of Acts as the "Acts of the Risen Lord" is accurate, in that it reports what Jesus continued to do in and through the apostles and prophets. The signs that accompany their ministry parallel his earthly ministry.

The origin of the title is thought by many to be derived from the Aramaic maran which, when translated in Greek communities as kyrios, was understood in terms of a savior God. Though it sounds plausible, in terms of linguistic history, the theory overlooks the fact that in all strata of the tradition (however these are finally defined) Jesus is portrayed as one who exercises divine prerogatives - such as forgiving sin, and being a "Son" in a way no other man has ever been a son of God. That type of immediate authority needs to be reckoned with alongside the linguistic data in any explanation of the title "Lord."

Scripture also speaks of the Lordship of Christ over all creation. In the grand Christological hymn included in Colossians 1:12-20, Paul speaks of Christ's relationship to the 
created order in terms that are parallel to his relationship to the Church, and thereby indicating that the rule of Christ is universal, that all of creation will ultimately come under his redemptive work. As the Church recognized the peculiar relationship of Jesus to the Father it was inevitable that it would come to define his work in terms that would involve all creation. This "cosmic Christology" is widely attested in the early Church. Not only do we find it in this possibly pre-Pauline hymn, ${ }^{29}$ but it is expressed by Paul himself in 1 Corinthians 8:6 in a way that suggests the readers were familiar with the theme. The writer of the epistle to the Hebrews begins his writing by referring to the creative work of Christ. Paul in Romans 8:19ff speaks of the ultimate deliverance from bondage of the whole created order. Finally, there is the Johannine prologue. In these passages Christ is seen as the one through whom all things were created; he sustains all things, that is, holds it all together to prevent a real disintegration of creation. ${ }^{30}$ Here we see an echo of the eschatological hope expressed, e.g., in Isaiah 2:4 when the harmony and unity of the created order is realized perfectly. It is an affirmation of God's creative activity, which is not to be undone or done away with, but is to find fulfillment through the redemptive work of the Son. Bo Reiche, in noting the very frequent use of $(\pi \alpha \varsigma \pi \grave{\alpha} \pi \dot{\alpha} v \tau \alpha)$ in the New Testament, refers to the concept of totality in the primitive Church. ${ }^{31}$ Piper considers it natural and unavoidable that the Church would regard its Lord as being involved not only in personal salvation but also in the ultimate purpose of God. ${ }^{32}$ All this comes to grand expression in Ephesians 1:10 where Christ is described as the one in whom ( $\dot{\varepsilon} v$ $\tau \tilde{\omega} \chi \rho(\sigma \tau \omega)$ all things find their consummation - are brought to purposive fruition. The Lordship of Christ and his redemptive work are seen to be co-extensive with Creation, for nothing lies beyond the concern of God. This is to be seen as an affirmation of this world and a commitment to it. At the same time all this means that without and apart from the work of the Son this present age is darkness - a void - and men labor in vain to find 
meaningful freedom. Apart from the Son all liberty is license, all hope is despair, and all love is vanity.

The final work of Jesus as Lord is to take place at his coming again when the work begun in his earthly ministry will be completed. He will come as Judge (Matthew 25:31ff) of all peoples. We find this theme primarily in apocalyptic form (Mark 13; Revelation; Matthew 25) but it is by no means limited to this literature, as we note from Acts 1:11; John 16:16, etc. This coming again is, indeed, the hope of the Church whose own witness will then be confirmed. It is that forward moment, that distant star, which provides for a steady course through treacherous history.

The descriptions of that moment and that event are varied and the Church will be cautious not to press for details (Acts 1:7). The nature of apocalyptic literature is to inform and impress, and its descriptive features serve only those ends. We are to know that he will come again, that we are to anticipate that coming, but to leave all details to the Father. In the meantime ours is to be the holy life and witness of power.

In closing an all too inadequate study of the person and work of Jesus I shall refer you to what is undoubtedly the one all-encompassing ascription of the early Church as to who and what Jesus is. John calls him the Word of God, by which of course he intended to bestow on Jesus all that is known by the Word. The Word is powerful; it goes forth only to inform and redeem. By the Word the Father comes to, and is known by, the world. Redemption and judgment- grace and truth- are by the Word of God. The Word is the extension of the Father in the world; by it the world is sustained (Hebrews 1:3). There is no knowledge apart from the Word, and so whoever believes not stands in judgment because he will not hear the only true Word. And so he- Jesus - is the fullness of God in that he fulfills the Father's redemptive purpose. He is Alpha and Omega. 
78 | The Person and Work of Jesus Christ

\section{Notes}

${ }^{1}$ Foundations of New Testament Christology (New York: Scribners, 1965), p. 15.

2 The Christology of the New Testament. ET (Philadelphia: Westminster, 1957), p. 1. For P. Althaus it is the person and history of Jesus Christ; see his The So-Called Kerygma and the Historical Jesus (Edinburgh: Oliver \& Boyd, 1959), p. 13.

${ }^{3}$ A survey of extra-biblical references to Jesus in F. C. Grant, "Jesus Christ," Interpreter's Dictionary of the Bible (Nashville and New York: Abingdon, 1962), Vol. II, p. 875f; cf. also H. Conzelmann in Religion der Geschichte and Gegenwart; 3. Auflage, III, 622.

${ }^{4}$ Cf. Adolf Schlatter, Der Glaube im Neuen Testament. 5. (Stuttgart: Calwer, 1963)

${ }^{5}$ Cf. Otto A. Piper, "The Virgin Birth: The Meaning of the Gospel Accounts," Interpretation, 18.2 (1964), 132-148.

${ }^{6}$ E.g., Mark 1:21, 39; 3:1; Matthew 4:32; 9:35; Luke 4:15f; 13:10f; John $6: 59 ; 18: 20$.

${ }^{7}$ Luke 19:1ff; 7:35ff; Matthew 11:28.

${ }^{8}$ A very helpful study of this issue may be found in David Catchpole, The Trial of Jesus (Leiden: Brill, 1971).

9 E.g., S. G. F. Brandon, Jesus and the Zealots (Manchester: The University Press, 1967) 
${ }^{10}$ John Knox, Christ the Lord (New York, 1945). R. Bultmann, Theology of the New Testament. I, p. 45 et passim; also "The Primitive Christian Kerygma and the Historical Jesus" in The Historical Jesus and the Kerygmatic Christ, eds. Braaten and Harrisville (1964), p. 42; Don Cupitt and C. F D. Moule, "The Resurrection: A Disagreement" in Theology, 75 (1972), 507-519; cf. also W. Marxsen, "The Resurrection of Jesus As a Historical and Theological Problem" in The Significance of the Message of the Resurrection for Faith in Jesus Christ, SBT, II. 8 (London: SCM, 1968), pp. 15-50.

${ }^{11}$ Isaiah 5 and 1 Samuel 12 with the parables of Mark 4 (parr.) Cf. C. H. Dodd, Parables of the Kingdom (London: Nisbet, second ed. 1961).

${ }^{12}$ Compare Mark 1:14; Matthew 9:35; 24:14; Luke 4:43; 8:1; 9:2; Acts 20:25; 28:31 with Acts 5:42; 8:35; 19:13; 1 Corinthians 1:23; 2 Corinthians 1:19; 11:4; Galatians 1:16.

${ }^{13}$ Mark 9:1; Matthew 6:10; 1 Corinthians 16:22.

${ }^{14}$ Mark 10:15; Matthew 25:34; Luke 8:40; John 1:12; 2 Corinthians 7:15.

${ }^{15}$ Mark 1:14; Matthew 12:28; Mark 9:1; Matthew 6:10; 18:20; 28:20; 1 Corinthians 16:22.

${ }^{16}$ Mark 9:47; Matthew 19:12; Luke 18:29; cf. Mark 10:29; Matthew 19:29; Romans12:1f; 2 Thessalonians 1:5.

17 Richard Longenecker, The Christology of Early Jewish Christianity, SBT, 2:17 (London: SCM, 1970), p. 71ff. cf. D. Flusser, Israel Exploration Journal, 9 (1959), 107ff.

${ }^{18}$ The following is only a small selection of what could be listed: M. Bluck, "The Son of Man Problem in Recent Research and Debate," BJRL, 45 (1963), 305-318; A. J. B. Higgins, "Son of Man-Forschung Since 'The Teaching of Jesus.'” New Testament Essays, ed. Higgins (Manchester, 1959), pp. 119-135; J. Y. Campbell, "The Origin and Meaning of the Term 'Son of Man,'” JTS 48 (1947), 145ff; M. P. Hooker, The Son of Man in Mark (London: SPCK, 1967). A. J. B. Higgins, Jesus and the Son of Man (Philadelphia: Fortress, 1964) H. E. 
Tödt, The Son of Man in the Synoptic Tradition, ET (London: SCM, 1965) F. H. Borsch, The Son of Man in Myth and History (Philadelphia: Westminster, 1967) I. H. Marshall, "The Son of Man in Contemporary Debate," Evang. Qu., 42.2 (1970), 67ff; Ragnar Leivestad, "Exit the Apocalyptic Son of Man," NTS, 18.3 (1972). 243-267.

${ }^{19}$ Theology of the New Testament, Vol. I, pp. $26 \mathrm{ff}$.

${ }^{20}$ In his book on Jesus, Schweizer titles one of his chapters, "The Man Who Fits No Formula"; see Jesus (Richmond: John Knox, 1971).

${ }^{21}$ Cf. E. Käsemann: "The only category which does justice to his claim (quite independently of whether he used it himself and required it of others) is that in which his disciples themselves placed him-namely, that of the Messiah." See, Essays on New Testament Themes, SBT, I. 41. (London: SCM, 1964), p. 38.

${ }^{22}$ E.g., H. Conzelmann, $\mathrm{RGG}^{3}$, III, 630.

${ }^{23}$ New Testament Theology: Vol. 1, The Proclamation of Jesus (New York: Scribners, 1971), p. 287.

${ }^{24}$ Isaiah 40-66. A Study of the Teaching of Second Isaiah and Its Consequences. Vet. Test. Supplement XIV, 1967 Chapter six.

${ }^{25}$ C. H. Dodd, however has argued for another interpretation of the "Lamb" in The Interpretation of the Fourth Gospel (Cambridge, 1953), pp. $230 \mathrm{ff}$.

${ }^{26}$ Vorlesungen über neutestamentliche Theologie (Leipzig, 1864), p. 158f. quoted from R. W. Dale, The Atonement, 18th edition (London, 1896), p. $477 f$.

${ }^{27}$ Gesammelte Aufsätze, 1970, p. 180.

28 Cf. C. F. D. Moule, An Idiom Book of New Testament Greek (Cambridge, 1953), p. 194.

${ }^{29}$ See R. P. Martin, Carmen Christi (Cambridge, 1967). 
Hebrews 1:3; Colossians $1: 16$; cf. B. F. Westcott on $\ddot{\alpha} \theta \varepsilon o l$ of Ephesians 2:12: "They were of necessity face to face with all the problems of nature and life, but without Him in Whose wisdom and righteousness and love they could find rest and hope. The vast, yet transitory, order of the physical universe was for them without its Interpreter, an unsolved enigma."

${ }^{31}$ TDNT, V, 893.

32 Interpretation, III. 3 (1949), 286-298. 


\section{Works Cited}

Bluck, M. "The Son of Man Problem in Recent Research and Debate," BJRL, 45 (1963).

Borsch, F. H. The Son of Man in Myth and History (Philadelphia: Westminster, 1967).

Bultmann, R. Theology of the New Testament.

"The Primitive Christian Kerygma and the Historical Jesus" in The Historical Jesus and the Kerygmatic Christ, eds. Braaten and Harrisville (1964).

Campbell, J. Y. "The Origin and Meaning of the Term 'Son of Man,'” JTS 48 (1947).

Cupitt, Don and Moule, C. F D. "The Resurrection: A Disagreement" in Theology, 75 (1972).

Dale, R. W. The Atonement, 18th edition (London, 1896).

Dodd, C. H. Parables of the Kingdom (London: Nisbet, second ed. 1961).

. The Interpretation of the Fourth Gospel (Cambridge, 1953).

Flusser, D. Israel Exploration Journal, 9 (1959).

Higgins, A. J. B. "Son of Man-Forschung Since 'The Teaching of Jesus."” New Testament Essays, ed. Higgins (Manchester, 1959).

. Jesus and the Son of Man (Philadelphia: Fortress, 1964).

Hooker, M. P. The Son of Man in Mark (London: SPCK, 1967).

Knox, John. Christ the Lord (New York, 1945).

Leivestad, Ragnar. "Exit the Apocalyptic Son of Man," NTS, 18.3 (1972).

Longenecker, Richard. The Christology of Early Jewish Christianity, SBT, 2.17 (London: SCM, 1970).

Marshall, I. H. "The Son of Man in Contemporary Debate," Evang. Qu., 42.2 (1970). 
Robert W. Lyon | 83

Marxsen, W. "The Resurrection of Jesus As a Historical and Theological Problem" in The Significance of the Message of the Resurrection for Faith in Jesus Christ, SBT, II. 8 (London: SCM, 1968).

New Testament Theology: Vol. 1, The Proclamation of Jesus (New York: Scribners, 1971).

Tödt, H. E. The Son of Man in the Synoptic Tradition, ET (London: SCM, 1965).

Vorlesungen über neutestamentliche Theologie (Leipzig, 1864). 


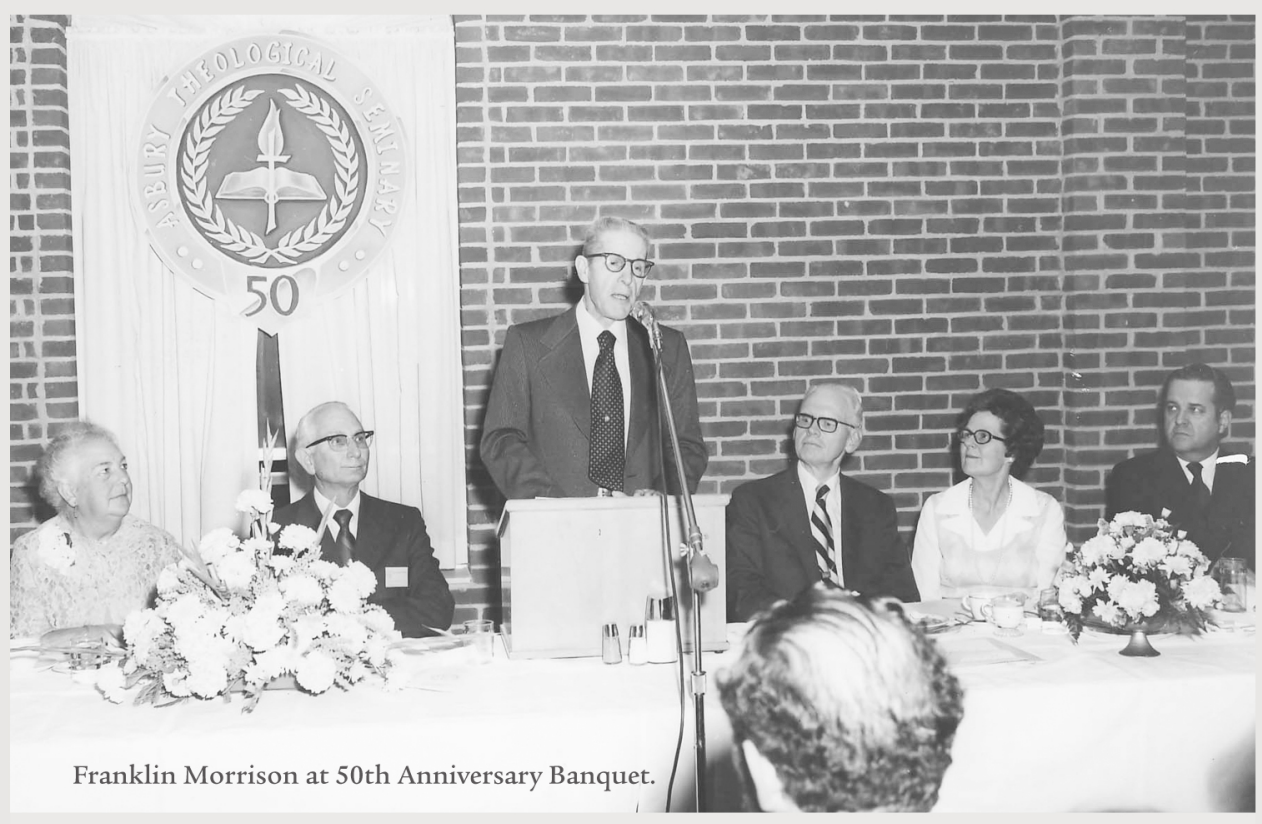

In honor of Asbury Theological Seminary's 90th anniversary, First Fruits Press has released several historic works published by the seminary in the past.

For its 40th anniversary in 1963, President Frank Stanger had three books published to celebrate the special event. These included a biography of Asbury Theological Seminary founder Henry Clay Morrison by Percival A. Wesche, a brief history of Asbury Theological Seminary by Howard Fenimore Shipps, and a volume of chapters on special theological emphases written by various faculty members. All three of these out-of-print works will now be released again as part of this special 90 th anniversary set.

On the 50th anniversary of Asbury Theological Seminary in 1973, President Stanger celebrated with a series of special lectures and scholarly papers to be given throughout the academic year of 1973-1974. Key faculty were assigned important theological topics and orally presented these papers in Estes Chapel. They have never been published until now in this special 90th anniversary set.

First Fruits Press is delighted to bring the voices of some of Asbury Theological Seminary's past to a new audience as we celebrate 90 years of serving God and spreading scriptural holiness throughout the world!

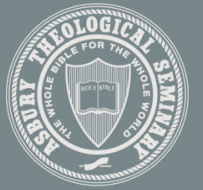

asburyseminary.edu

800.2ASBURY

204 North Lexington Avenue

Wilmore, Kentucky 40390 